\title{
Household Amenities and Urban Infrastructure Development of Hisar City, 2010
}

\author{
Rajeev $^{1}$, Dr. Satya Prakash Kaushik ${ }^{2}$ \\ ${ }^{1}$ Research Scholar, Geography Department, Kurukshetra University, Kurukshetra \\ ${ }^{2}$ Professor, Geography Department, Kurukshetra University, Kurukshetra
}

\begin{abstract}
The world has been facing problem of degradation in every sphere. Cities are experiencing very high growth of population. This has put excessive pressure on the existing resources and civic amenities. Sustainability is the key world in today's world. In fact it is the only way we can save our planet. A city has to fulfill certain criteria in order to become sustainable city and there is an urgent need to follow holistic approach to achieve the goal of sustainable urban development. Urban community development and urban planning integrates land use planning and urban renewal to improve the built and social environments of communities by adapting urban planning methods to existing cities suffering from decay and lack of investment. Sustainable development and sustainability influence today's urban planners. Some planners say that modern lifestyles use too many natural resources, polluting or destroying ecosystems, increasing social inequality overheating urban heat islands, and causing climate changes.
\end{abstract}

Keywords: Households, Field Survey, GIS, Census data, ROW (Right of Way), NCR,

\section{Introduction}

Rapid growth of urban population and low investment in urban development has created serious deficiencies in the availability of infrastructure in the towns and cities of the country. Haryana would experience a very high growth of urban population particularly in surrounding areas of national and state capitals and along national highways passing through the state. Therefore, it is high time to regulate it through a holistic approach involving people and experts from different walks of life. There must be check on encroachments, unplanned growth and violations. It is also time for the planners to rethink about the existing laws related to the development of road network. The existing restrictions on the construction activities within certain limit of right of way (ROW) from the centre of the different level of roads have failed to improve accessibility. Decentralization of development activities in the non-NCR areas can solve many of the urban problems of the large industrial centers like Faridabad, Panipat and Yamuna Nagar. Moreover, it is also necessary to develop the areas, which have lagged behind.

\section{Statement of the Problem}

The present town has the institute of higher education namely technical university and agriculture university. Students have to move to different educational institutes for higher education located at Kurukshetra, Delhi, and other big cities like Chandigarh. Regarding health, government and other private hospitals are there but in some cases for better services patients move to Chandigarh, Rohtak and Delhi for getting better health facilities. Most population of the town is based on non-agricultural activities therefore, the per capita income of the town is good as compare to small towns. The present town is an industrial town. Jindal steel factory and other industries are located there. Due to industrializations there are many urban problems in the city such as inadequate parking facilities, traffic congestion, particularly at peak times, limited open space, urban crime, inadequate housing, poverty and environmental pollution. One important problem is the rapidly growing population of the city and its suburb. Other major problems of present town are the difficulties in maintaining supplies of water in some areas, electric power and mismatch between the locations of civic and social services. There are variations in the infrastructure development of the city due to industrialization and environmental factors.

\section{Objectives}

The main objective of the present study remains to; Identify the ward wise variation in the level of household amenities and urban infrastructure development.

\section{Research Methodology}

Present study has carried out detailed analysis of social wellbeing, economic, health and infrastructural aspect of the population. The study is based on field survey, secondary data and GIS related data.

\subsection{Data base}

Information such as population details of each ward, ward wise map of study area and district gazetteer were collected from municipal committee Hisar and statistical department of Hisar. The digitized map of study area and information map (Hisar constituency) were collected from Haryana Space Application Center (HARSAC) Hisar. Explanatory data for the purpose of comparison of Hisar with Haryana and India has been taken from statistical abstract of Haryana and India, 2001 and provisional population tables, census of India, 2011. The study is largely based on field survey. The questionnaire consists of data related to social, economic, health, and demography and infrastructure aspects. 


\section{International Journal of Science and Research (IJSR) \\ ISSN (Online): 2319-7064 \\ Index Copernicus Value (2013): 6.14 | Impact Factor (2014): 5.611}

\subsection{Sample Selection}

The study is based on 477 samples which is one percent of the total households of the study area. Sample households were selected in proportion to ward population. Samples were collected randomly within each ward. The author has also conducted personal interviews of the Hisar"s households. The author personally went to each ward of study area and put questions related to householdes information and get information about social and economic development of urban area.

\subsection{Data processing}

The collected data is tabulated and processed with the help of simple statistical techniques such as percentage and ratio. Level of social, economic, and infrastructural development is worked out with the help of composite Z-score. Similarly, population characteristics like age and sex composition of population, literacy rate, per capita income, were calculated and analyses with the help of simple statistical techniques. The processed data is cartographically represented by maps prepared in Arc GIS 9.3.1, Desktop editor and Arc Info. SPSS 12.1 is also used for calculation of standard deviation and mean. AutoCAD map 2000i is also used for map digitization.

\section{Study Area}

Hisar city located at $29^{0} 10^{\text {ee }}$ north latitude and $75^{\circ} 45^{\text {ce }}$ east longitude, is one of the important and fast growing urban center of Haryana. Hisar has grown to a vital position on the urban map of Haryana.

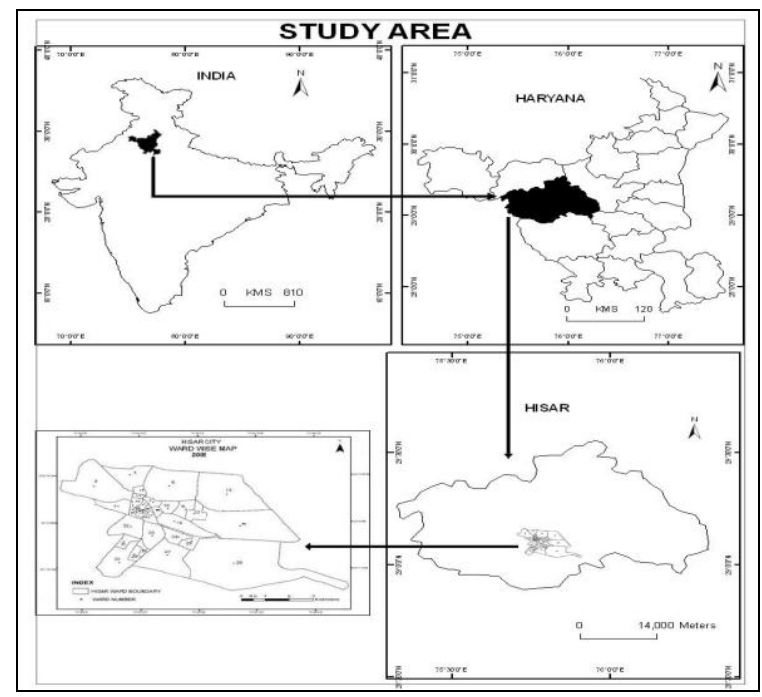

Figure 1

It has come up because of its location factors. Its location is such that for any development away from grand trunk road and railway line. Hisar drawn attention city of Faridbad, Gurgoan and Rohtak have different reasons for there growth where as Hisar city is growing entirely on its potential to grow and its nodality in the region.

\subsection{Origin of the Name of the Town}

The city of Hisar was founded by a Muslim ruler, Firozshah Tughlaq in 1354 A.D. „Hisare is an Arabic word which means ,Forte. The city, which we know today as „Hisare, was originally called „Hisar Firoza (also Hisar-e-Firoza) or in other words the ,Fort of Firoz ${ }^{\text {ec }}$. But as the days rolled by, the word ,Firoza ${ }^{e e}$ was dropped from its original name.

It gained importance in early sixties when agriculture university, was setup as an extension of the Punjab Agriculture University, Ludhiana. Ever, since, the government's positive polices and good behaviors have played a vital role in the economic development of the city.The industrial policy of the government has attracted large number of entire preneurs and has resulted into the industrialization in around the city the construction of a new judicial complex and district administrative complex, shifting of Haryana state electricity board offices, setting up of cantonment and development a new residential sectors have made this city a strong growth center in the region in Haryana.

\subsection{Quality of House, Household Amenities and Infrastructure Development}

Rapid growth of urban population and low investment in urban development has created serious deficiencies in the availability or infrastructure in the town and cities of the country. The present study covered all the issues like, quality of home, household's amenities, drinking water, and other basic needs of households.

\subsubsection{Quality of House}

Table 1 Hisar: Quality of House, 2010

(In Percent)

\begin{tabular}{|c|c|c|c|}
\hline House & Pucca & Semi Pucca & Kutcha \\
\hline Social Group & \multicolumn{3}{l}{} \\
\hline Low & 60.83 & 35.00 & 4.17 \\
\hline Middle & 75.57 & 22.16 & 2.27 \\
\hline High & 87.29 & 12.71 & - \\
\hline Total & 76.31 & 21.80 & 1.89 \\
\hline Income Group \\
\hline$<2300$ & 25.00 & 25.00 & 50.00 \\
\hline $2300-4600$ & 29.17 & 62.50 & 8.33 \\
\hline $4600-6900$ & 41.05 & 54.74 & 4.21 \\
\hline$>6900$ & 89.55 & 10.17 & 0.28 \\
\hline Total & 76.31 & 21.80 & 1.89 \\
\hline
\end{tabular}

Source: Field Survey of Hisar, 2010

Table 1 shows that 76.31 percent houses are pucca. There are 21.80 percent houses which are semi pucca and only 1.89 percent houses are kutcha. Proportion of pucca houses is more in higher social group as compare to low social group. In low social group 60.83 percent houses are pucca which increased to 75.57 percent in middle social group and 87.29 percent in high social group. In high social group there is no kutcha house. Similarly, in very low income group 25 percent houses are pucca which increased to 29.17 percent in low income group, 41.05 percent in middle income group and 89.55 percent in high income group. In very low income group 50 percent houses are kutcha. The income level of high social group is high as compare to low social income 


\section{International Journal of Science and Research (IJSR) \\ ISSN (Online): 2319-7064 \\ Index Copernicus Value (2013): 6.14 | Impact Factor (2014): 5.611}

group. Therefore, it is implied that income is positively related to pucca houses.

\subsubsection{Household Amenities}

Table 2 reveals that about 81.13 percent house in the city have separate kitchen and 96.86 percent houses have bathroom facility. It is interesting that 100 percent houses have latrine facility. In low social group 67.23 percent houses have separate kitchen which increased to 85.87 percent in middle and high social group. Similarly, 50 percent houses have separate kitchen in very low income group which increased 59.09 percent in low income group, 57.29 percent in middle income group and 89.30 percent in high income group. In high income group proportion of separate kitchen is very high as compare to other income group. Therefore, it is implied that income is positively related to availability of separate kitchen and other amenities in houses.

Table 2: Hisar: Access to Household Amenities, 2010

\begin{tabular}{|c|c|c|c|}
\hline \multicolumn{4}{|c|}{ (In Percent) } \\
\hline Social Group & Kitchen & Bathroom & Latrine \\
\hline Low & 67.23 & 93.80 & 100.00 \\
\hline Middle & 85.87 & 97.74 & 100.00 \\
\hline High & 85.64 & 98.69 & 100.00 \\
\hline Total & 81.13 & 96.86 & 100.00 \\
\hline Income Group & 50.00 & 75.00 & 100.00 \\
\hline$<2300$ & 59.09 & 72.73 & 100.00 \\
\hline $2300-4600$ & 57.29 & 93.75 & 100.00 \\
\hline $4600-6900$ & 89.30 & 99.44 & 100.00 \\
\hline$>6900$ & 81.13 & 96.86 & 100.00 \\
\hline Total
\end{tabular}

Source: Field Survey of Hisar, 2010

There are about 96.86 percent houses which have bathroom. In low social group 93.80 percent houses have bathroom which increased to 97.74 percent in middle social group and 98.69 percent in high social group. Similarly, 75 percent houses have bathroom in very low social group which decreased to 72.73 percent in low social group and again increased 93.75 percent in middle income group and 99.44 percent in high income group. Therefore, high income group people have high percentage of availability of bathroom in houses.

\subsubsection{Availability of Latrine}

There are about 100 percent houses in the city have latrine. Latrine facility is the main or basic needs of the houses in urban area. It is interesting that there is no house without latrine facility. People of urban area are more aware about these basic needs and the importance of hygiene.

\subsubsection{Availability of Drinking Water}

Table 3 shows that availability of drinking water is studied with respect to social and income level. Drinking water is also basic needs of household. About 92.87 percent out of total respondents have facilities of drinking water within premises on the other hand only 7.13 percent respondents have to often drinking water from outside the premises. 91.16 percent households have facility of drinking water within premises in low social group which increased to 92.09 percent in middle social group and 96.09 percent in high social group.

Table 3 Hisar: Availability of Drinking Water, 2010

(In Percent)

\begin{tabular}{|c|l|c|}
\hline $\begin{array}{l}\text { Availability of } \\
\text { Drinking Water }\end{array}$ & $\begin{array}{l}\text { Within } \\
\text { Premises }\end{array}$ & Outside Premises \\
\hline Social Group \\
\hline Low & 91.16 & 8.84 \\
\hline Middle & 92.09 & 7.91 \\
\hline High & 96.09 & 3.36 \\
\hline Total & 92.87 & 7.13 \\
\hline Income Group \\
\hline$<2300$ & 75.00 & 25.00 \\
\hline $2300-4600$ & 90.91 & 9.09 \\
\hline $4600-6900$ & 92.68 & 7.32 \\
\hline$>6900$ & 94.79 & 5.21 \\
\hline Total & 92.87 & 7.13 \\
\hline \multicolumn{3}{|c|}{ Source: Field Survey of Hisar, 2010}
\end{tabular}

Similarly, 75 percent households have facility of drinking water within premises in very low income group which increased to 90.91 percent in low income group, 92.68 percent in middle income group and 94.79 percent in high income group. Drinking water is the main problem of study area. Some localities of study area uses ground where ground water is good. These localities have duel facility of drinking water. They have access to handpump outside their premises as well as piped water supply from municipality. Most households preferred handpump water for drinking purposes and piped water for other uses. Only seven percent households have facility of drinking water outside premises.

\subsubsection{Sources of Drinking Water}

Table 4 Hisar: Source of Drinking Water, 2010

(In percent)

\begin{tabular}{|c|c|c|}
\hline Source of Drinking Water & Piped Water & Hand Pump \\
\hline Social Group & 82.35 & 17.65 \\
\hline Low & 84.18 & 15.81 \\
\hline Middle & 90.05 & 9.95 \\
\hline High & 85.96 & 14.04 \\
\hline Total & 70.00 & 30.00 \\
\hline Income Group & 73.68 & 26.32 \\
\hline$<2300$ & 79.21 & 20.79 \\
\hline $2300-4600$ & 88.67 & 11.33 \\
\hline $4600-6900$ & 85.96 & 14.04 \\
\hline$>6900$ & Total &
\end{tabular}

Source: Field Survey of Hisar, 2010

Table 4 shows that source of drinking water is studied with respect to social and income level. Piped water is considered as the most hygienic and safe. About 85.96 percent households use piped water, 82.35 percent households use piped water in low social group which increased to 84.18 percent in low social group and 90.05 percent in middle

\section{Volume 4 Issue 12, December 2015}




\section{International Journal of Science and Research (IJSR) \\ ISSN (Online): 2319-7064 \\ Index Copernicus Value (2013): 6.14 | Impact Factor (2014): 5.611}

social group. Similarly, 70 percent households use piped water in very low income group which increased to 73.68 percent in low income group, 79.21 percent in middle income group and 88.67 percent in high income group. Therefore, it is implied that income is positively related to availability of piped water.

\subsubsection{Percentage of Household Use Energy for Preparing Food}

Table 5 shows that 94.13 percent household have used cooking gas for preparing food. There are 2.73 percent household which have used wood/cow-dug. Only two percent households which have used oil stove for preparing food. Proportion of household in which cooking gas is used more is higher social group or income group as compare to low social group or very low income group. About 86.56 percent household in low social group used cooking gas which increased to 94.62 percent in middle social group and 98.34 percent in high social group.

Table 5 Hisar: Household Used Energy for Prepaning Food, 2010

\begin{tabular}{|c|c|c|c|c|c|}
\hline Fuel & $\begin{array}{l}\text { Gas/Stove } \\
\text { cylinder }\end{array}$ & $\begin{array}{l}\text { Oil } \\
\text { stove }\end{array}$ & Heater & Coal & $\begin{array}{l}\text { Wercent) } \\
\text { Wood } \\
\text { Cow Dug }\end{array}$ \\
\hline \multicolumn{6}{|l|}{ Social Group } \\
\hline Low & 86.56 & 3.36 & - & 2.52 & 7.56 \\
\hline Middle & 94.92 & 1.69 & 1.13 & 0.56 & 1.70 \\
\hline High & 98.34 & 1.10 & - & - & 0.56 \\
\hline Total & 94.13 & 1.89 & 0.41 & 0.84 & 2.73 \\
\hline \multicolumn{6}{|l|}{ Income Group } \\
\hline$<2300$ & 25.00 & 25.00 & - & - & 50.00 \\
\hline $2300-4600$ & 63.64 & 13.64 & - & 9.09 & 13.63 \\
\hline $4600-6900$ & 87.50 & 3.12 & 1.05 & 2.08 & 6.25 \\
\hline$>6900$ & 98.59 & 0.56 & 0.28 & - & 0.57 \\
\hline Total & 94.13 & 1.89 & 0.41 & 0.84 & 2.73 \\
\hline
\end{tabular}

Source: Field Survey of Hisar, 2010

Similarly, in very low income group, it is only 25 percent which increased to 63.64 percent in low income group, 87.50 percent in middle income group and 98.59 percent in high income group. About 50 percent households in very low income group used wood/cow-dung for preparing food. Therefore, it is implied that income is positively related to availability of cooking gas.

\subsubsection{Composite Index of Household Amenities and Infrastructure Development}

Fig. 2 shows that the infrastructure development of wards. The very low developed wards are 5, 10, 11, 13, 14, $15,16,19,21$ and 22. Low developed wards are 8, 18,20,23,24 and 26. Moderate developed wards are 1, 2,3,4,28,31 and 32. High developed wards are 6, 7, 9, 12, 17, 25, 27, 29 and 30. There are about 76.31 percent houses of the city are pucca. Ward no. 1, 2, 4, 5, 6,7,12, 20, 24, 25, 27, 29, 30 and 32 have high percentage of pucca houses. Ward no. 3,10,13,15, $17,18,21,22,23,26,28$ and 31 have a moderate percentage of pucca houses. Ward no. 8, 9,11,14,16 and19 have low percentage of pucca houses, because these wards are more congested and low income people live in above wards.
Income is positively related to pucca houses. Most of people who belong to low social group and very low income group are living in the above wards, so pucca houses percentage is low in these wards. Proportion of pucca houses in study area is fairly high which 76.31 percent is. It is because per capita income of the people is good and job opportunity is also well due to industrialization and well established public sector including establishment of Agriculture University.

Table 6 Hisar: Composite Index of Household Amenities and Infrastructure Development, 2010

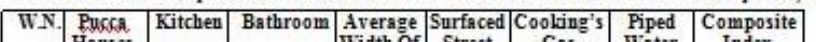

\begin{tabular}{|c|c|c|c|c|c|c|c|c|}
\hline 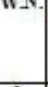 & Houses & (2) & 年 & $\begin{array}{l}\text { Average } \\
\text { Width Of } \\
\text { Street } \\
\text { Street. }\end{array}$ & $\begin{array}{l}\text { Surtacea } \\
\text { Street }\end{array}$ & Gas & $\begin{array}{l}\text { Fped } \\
\text { Water }\end{array}$ & $\begin{array}{l}\text { Inposite } \\
\text { Index }\end{array}$ \\
\hline 1. & 80.00 & 100.00 & 100.00 & 18.19 & 100.00 & 80.00 & 80.00 & 0.98 \\
\hline 2. & 80.00 & 100.00 & 100.00 & 15.42 & 100.00 & 100.00 & 68.75 & 091 \\
\hline 3. & 70.59 & 77.78 & 94.44 & 16.48 & 94.45 & 100.00 & 88.24 & 0.32 \\
\hline 4. & 80.00 & 100.00 & 100.00 & 13.26 & 100.00 & 100.00 & 80.00 & 0.99 \\
\hline 5. & 83.33 & 66.67 & 83.34 & 14.07 & 100.00 & 100.00 & 83.33 & -2.58 \\
\hline 6. & 100.00 & 100.00 & 100.00 & 14.68 & 100.00 & 100.00 & 100.00 & 5.56 \\
\hline 7. & 80.00 & 100.00 & 100.00 & 15.47 & 100.00 & 100.00 & 100.00 & 4.79 \\
\hline 8. & 45.45 & 81.82 & 100.00 & 1397 & 100.00 & 90.91 & 90.00 & -192 \\
\hline 9. & 55.56 & 100.00 & 100.00 & 15.23 & 100.00 & 100.00 & 100.00 & 3.13 \\
\hline 10. & 65.52 & 65.52 & 96.55 & 1426 & 100.00 & 93.10 & 82.76 & -2.59 \\
\hline 11. & 54.55 & 45.54 & 100.00 & 13.96 & 100.00 & 100.00 & 81.82 & -3.17 \\
\hline 12. & 84.62 & 84.62 & 100.00 & 17.47 & 100.00 & 100.00 & 83.33 & 3.31 \\
\hline 13 & 6190 & 57.14 & 90.48 & 18.29 & 74.04 & 90.91 & 85.71 & -5.69 \\
\hline 14. & 59.26 & 9630 & 74.07 & 16.65 & 81.48 & 96.30 & 85.18 & -5.34 \\
\hline 15. & 64.71 & 64.71 & 88.24 & 1597 & 100.00 & 88.89 & 82.35 & -3.69 \\
\hline 16. & 55.56 & 66.67 & 100.00 & 14.24 & 77.78 & 100.00 & 77.78 & -5.48 \\
\hline 17. & 71.43 & 85.71 & 100.00 & 13.28 & 100.00 & 100.00 & 85.72 & 0.33 \\
\hline 18. & 66.67 & 100.00 & 100.00 & 13.45 & 100.00 & 83.33 & 88.33 & -1.17 \\
\hline 19. & 50.00 & 100.00 & 100.00 & 16.28 & 100.00 & 83.33 & 66.67 & -3.18 \\
\hline 20. & 80.00 & 80.00 & 100.00 & 18.33 & 100.00 & 80.00 & 80.00 & -0.12 \\
\hline 21. & 62.50 & 42.86 & 85.71 & 15.20 & 100.00 & 100.00 & 85.71 & -392 \\
\hline 22. & 64.29 & 71.43 & 100.00 & 14.57 & 92.89 & 92.86 & 78.57 & -3.18 \\
\hline 23. & 60.00 & 70.00 & 100.00 & 13.26 & 100.00 & 100.00 & 80.00 & -2.02 \\
\hline 24. & 100.00 & 72.22 & 100.00 & 14.68 & 94.45 & 94.74 & 77.78 & -0.44 \\
\hline 25. & 100.00 & 94.12 & 100.00 & 17.24 & 100.00 & 100.00 & 88.24 & 530 \\
\hline 26. & 78.34 & 88.33 & 98.34 & 15.63 & 93.34 & 91.66 & 83.33 & -0.42 \\
\hline 27. & 95.45 & 95.45 & 100.00 & 18.30 & 100.00 & 100.00 & 95.65 & 6.65 \\
\hline 28. & 72.73 & 90.91 & 100.00 & 15.78 & 100.00 & 90.00 & 81.82 & 0.25 \\
\hline 29. & 100.00 & 100.00 & 100.00 & 17.86 & 100.00 & 100.00 & 100.00 & 7.48 \\
\hline 30. & 92.00 & 86.00 & 96.00 & 16.98 & 100.00 & 90.00 & 92.00 & 2.49 \\
\hline 31. & 70.00 & 90.00 & 100.00 & 13.45 & 100.00 & 100.00 & 90.00 & 1.13 \\
\hline 32 . & 100.00 & 100.00 & 100.00 & 14.56 & 100.00 & 84.62 & 84.62 & 1.29 \\
\hline
\end{tabular}

There are about 81.13 percent houses have separate Kitchen. Ward no. 1,2,4,6,7,9,14,18,19,25,27,28 and 29 have high percentage of houses with separate kitchen. Ward no.

Figure 2

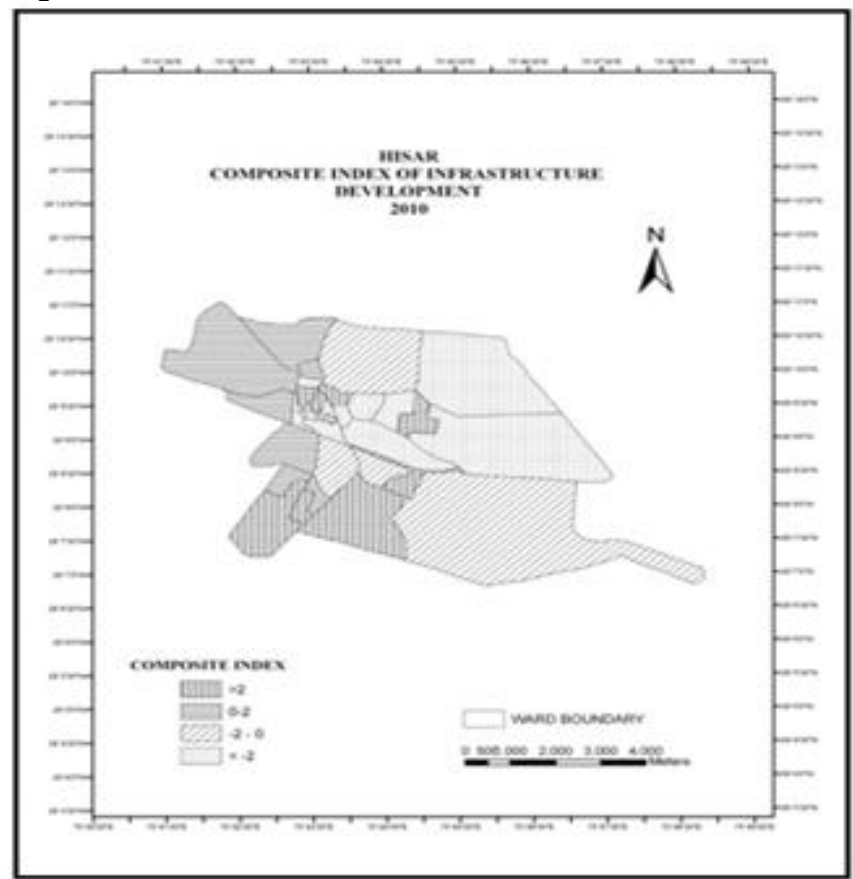




\section{International Journal of Science and Research (IJSR) \\ ISSN (Online): 2319-7064}

Index Copernicus Value (2013): 6.14 | Impact Factor (2014): 5.611

$8,12,17,26$ and 30 have moderate percentage of separate kitchen in houses. Ward no. 3,5,10,11,13,15,16,20,21,22,23 and 24 have low percentage of separate kitchen. The income level of above wards is low as compare to other wards. Most of people who belong to low social group and very low income group living in the above wards so percentage of houses in which there are separate kitchen is low. In low income group people do not prefer separate kitchen and bathroom facility due to low income.

There are about 96.86 percent houses have bathroom. Ward no. $1,2,3,4,6,7,8,9,10,11,12,13,16,17,18,19,20,22,23,24,25$, $26,27,28,29,30,31$ and 32 have a high percentage of houses in which there are bathroom. Ward no. 5, 15 and 21 have moderate percentage of houses which have bathroom. Ward no. 14 is the only ward in which low percentage of bathroom. Those people who belong to high income and high social group have high percentage of bathroom as compare to other wards, so income and occupation of the households play an important role.

The average width of the street in the city is 15.62 feet. Ward no. $1,3,12,13,14,19,20,25,27,29$ and 30 have a high average width of street. Ward no. 2,5,6,7,9,10, 15, 16, 21, $22,24,26,28$ and 32 have a moderate average width of street. Ward no. 4,8,11,17,18,23 and 31 have low average width of street. Above wards is more congested in city due to very low width of the street. Wards no. 4, 11, 18 and 31 has very low width of street. Most streets of these wards have very low average width being part of old city.

There are about 94.13 percent households in which cooking gas is available for preparing food. Proportion of households used cooking gas for preparing food. Ward no. $2,3,4,5,6,7,9,11,12,14,16,17,21,23,25,27,29$ and 31 have a high percentage of houses in which cooking gas is available. Ward no. 8,10,13,22,24,26,28 and 30 have a moderate percentage of houses in which cooking gas is available. Ward no. 1,18,19,20 and 32 have a low percentage of houses in which cooking gas is available. Only 2.73 percent households have used wood/cow dung for preparing food. Number of households in ward no. 18, 19, 20 and 32 belong to low social group and very low income group, so percentage of houses in which cooking gas is available is low.

There are about 85.96 percent households have access to piped water supply. About 14.04 percent households use hand pump water. No family in the study area depends on well. Ward no. 6, 7, 9, 27, 29, 30 and 31 have a high percentage of households which have access to piped water supply. Ward no.3, 4, 5, 8, 10,11 ,12 ,13,14,15, 17,18,20, $21,23,25,26,28$ and 32 have a moderate percentage of households which have access to piped water supply. Ward no. 2,16,19,22 and 24 have a low percentage of households which have access to piped water supply. These indicators play an important role in infrastructure development. Ward no. $6,7,9,12,17,25,27,29$ and 30 are high developed ward and in these some political leaders are also lived so these are highly developed.

\section{Conclusions}

The present study shows that the proportion of pucca houses in Hisar is fairly high which 76.31 percent. There are about one fourth percent houses are semi pucca and 1.89 percent houses are kutcha houses. It is because per capita income of the people is good and job opportunity is also well due to industrializations and well establishment of public sector including establishment of Agriculture University. Income is positively related to pucca houses.

The basic amenities in Hisar are satisfactory, such as bathroom, latrine, separate kitchen, telephone, newspaper, cooking gas and transport facilities. There are about 63.94 percent households have motor cycle/scooter. It is interesting that there is no house without latrine facility. People in urban area are more aware about their basic needs and the importance of hygiene. Drinking water is basic needs of households. Overwhelming proportion of households (92.87 percent) has facilities of drinking water within premises. Drinking water is the main problem in study area. Some localities of Hisar use ground water (ward no. 4, 5 and 10) where ground water is good for drinking purpose. These localities have duel facility of drinking water. So water supply should be augmented by recycling of waste water thorough water treatment plants and by adopting water harvesting techniques. The study area has recorded a significant change in residential area due to continuous increasing population. So the city expends towards countryside area. One main point is that the commercial areas have increased in the central part of the city that too along the main roads. These areas are very high land value zone and that is why commercial areas have pushed residential areas away to the outer part of the city. Condition of roads and basic amenities in the old part of the city (ward no. $4,8,11,17,18,23$ and 31) do not match with the other parts of the city, which need complete overhauling.

\section{References}

[1] Amita, S. and Reddy, K.S., (2006), "Highlighting the Tenets of Sustainable Development," Current Science, Vol.90, No. 5, pp. 727-728.

[2] Bhargawa, A., (1989), "Globalization, Literacy Levels and Economic Development," In the Poor Under Globalization in Africa, Asia and Latin America, Edited By Nissanke and Thorbecke, E., Oxford University Press, USA.

[3] Chowbey, P.K. , (1994) , “A New Index of Urbanization and Quest for Alternatives," India , Journal of Regional Science, Vol. XXVI, No. 1, Published by Regional Science Association, India, Indian Institute of Technology, Kharagpur.

[4] Datta,S.K.and Mukhopadhyay,F., (1999), "Industrial Disparities in India A Test of Convergence," Indian Journal of Regional Science,vol.1,no.1,pp.19-30, published by Regional Science Association, India, Indian Institute of Technology, Kharagpur.

[5] Documentation, (2009), "Delhi Human Development Report an Overview", Indian Journal of Human Development, Vol. 1, No. 1, pp 200-230. 
[6] Kaushik, S.P., (2001), "Spatial and Structural Pattern of Urban Population and Its Social and Economic Attributes in Haryana", Indian Journal of Geography and Environment, Vol. 8 and 9 : 2003-2004, Vidya Sagar University ,Medinipur West Bengal, India, pp. 52-63.

[7] Sinha, S.P., (1984), "Processes and Pattern of Urban Development in India: A Case Study of Haryana", The Associated Publishers, Ambala Cantt.

\section{Internet:}

[8] Moses, K. T., (2000), "The Environment and Development in Africa," Rowan and Littlefield Publishing Group, USA, pp. 62-70. Reddy (2009), All+Contribution +Aspects of Social+Well-being,html/ page and Spence, Annez and Buckeley, 2009+ urbanization +development., http://www.idea.repec.com/india.

[9] Sanhita, B., (2008), "Way to Sustainable Development of Urban Management : Green City in India," The European Journal of Planning, Published By Programme, Ministry of and Environment Forest, Government of India., http://www.planum.net/topic/documents/sanhitabandy.pd $\mathrm{f}$

Government Publications:

[10] Census of India (2007-08): District Census Hand Books, Hisar, Government of Haryana, pp. 8-35.

[11]Haryana Government Gazetteer (1987): District Gazetteer of Hisar, January 19, 1987, Government of Haryana, pp. 6-25.

Government Offices

[12]HARSAC ( Haryana Space Application Center), Haryana Agriculture University Hisar,

[13] District Statistical Office , Mini Secretariat, Hisar, Haryana

Municipal Committee ,Hisar

[14]Department of Town and Country Planning, Hisar, Haryana

\section{Author Profile}

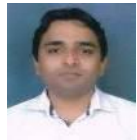

Rajeev. did M.Phil. in Geography from Kurukshetra University in 2012 and P.G. Diploma in Remote Sensing and GIS from Uttarakhand Open University in Uttarakhand, 2015, and currently I am working as a JRF/Project Fellow in HARSAC, Department of Science and Technology, CCS, HAU Campus, Hisar.

Dr. Satya Prakash Kaushik - M.A., M.Phil \& Ph.D Jawaharlal Nehru University, Delhi and Currently working as Professor in Department of Geography, Kurukshetra University in Kurukshetra, India 